\title{
Kas õpi- või õpperuum? \\ Mõistekasutus loob arusaama õppimise sisust
}

\author{
KATRIN AAVA, KATRIN KARU, ESTA KAAL, MARI UUSKÜLA
}

Sellega, kuidas mõistame õppimise tähendust, mõtestame inimeseks olemist ning kujundame ühiskonnas inimestevahelisi ja institutsionaalseid suhteid, mõjutades nii kõiki ühiskonna liikmeid. Õpikäsitus ongi arusaam sellest, mis eesmärkidel ja kuidas õpitakse ja millistes suhetes on selles protsessis osalejad, ning selle arusaama rakendamine praktikas (HTM 2017). Õpikäsitused on ajas muutuvad ühiskondlikud kokkulepped, mis on seotud inimeste uskumuste, tavade ja suhetega, ning väljenduvad nii oskuskeeles kui ka tavakasutuses. Keelekasutus on valik, mis lähtub teksti looja vaatepunktist; tekstid luuakse kultuurilises ja majanduspoliitilises kontekstis, loomulikustatakse ehk muudetakse iseenesestmõistetavaks igapäevases kasutuses (Kasik 2008). Kuna õpikäsitused muutuvad, on oluline mõista, kuidas õppimisega seotud sõnu kasutatakse. Oleme mõistnud, et õpetamise ja õppimise küsimustes seisukohti võttes lähtutakse nendest diskursustest, mida on hakatud eri põhjustel kehtivaks pidama. Nii võib tekkida olukord, kus üks kujutlus õpetamisest ja õppimisest on muutunud nõnda ülekaalukaks, et ei suudeta enam mõista mitmekesiseid nüüdisaegseid arusaamu (Säljö 2003), näiteks sotsiaalkonstruktivistlikku õpikäsitust.

Artiklis põhjendame, miks just õpiruumi mõiste võib edasi anda sotsiaalkonstruktivistlikku õpikäsituse sisu ning rõhutada muutunud arusaamu õppimisest. Selgitame, kuidas see mõiste teeb nähtavaks suhted ja tegevused, mis õppimist toetavad. Võrdlevalt avame sõnade ópiruum ja õpperuum näitel, kas ja kuidas antakse nende kaudu tarbetekstides edasi arusaamu õppimisest ning hariduses osalejate suhetest õpiprotsessis. Selgub, et tarbetekstides kinnistatakse mõlema sõnaga seni levinud õpikäsitust ning leidub isegi sisuliselt vastuolulisi mõttekonstruktsioone. Näiteks leidsime meediatekstis lause „Avatud õpiruumi pääsevad õpilased siis, kui õpetaja selle ukse kiipkaardiga avab". Seetõttu on oluline ühtlustada mõistevara ja artiklis pakumegi õpiruumi mõistele uue sisu.

\section{Keelekasutus loomulikustab ühiskondlikud õppimise ja õpetamise kokkulepped}

Õpikäsitusi on paigutatud erinevatesse psühholoogilis-filosoofilistesse teoreetilistesse raamistikesse: näiteks Soome kasvatusteadlased Päivi Tynjälä jt (2005) toovad esile biheiviorismi, kognitivismi ja konstruktivismi; Rootsi uurija Roger Säljö (2003) liigitab õppimise ja arengu uurimise teoreetilised traditsioonid biheiviorismiks ja kognitivismiks. Eesti kasvatusteadlane Tiiu Kuurme (2015) nimetab levinumateks 
biheivioristlikku, humanistlik-kogemuslikku, kognitivistlikku ja konstruktivistlikku õpikäsitust. Sharan B. Merriam jt (2007) selgitavad õppimist biheivioristlikust, humanistlikust, kognitivistlikust, sotsiaal-kognitivistlikust ja konstruktivistlikust vaatepunktist lähtuvalt. Haridusteadlane Edgar Krull (2013) esitab haridusleksikonis kolm võimalust: biheivioristlikus õpikäsituses nähakse õppimist signaalidele reageerimisena, kognitivistlikus teadmiste omandamisena ja konstruktivistlikus teadmiste konstrueerimisena, sotsiaalkonstruktivistliku käsituse järgi on õppimine muutus ühiskondlikus praktikas ehk kultuuris osalejates. Krull rõhutab, et kõik need käsitused aitavad avada õppimise kompleksset sisu, lähtudes erinevatest otstarvetest ja vaatepunktist.

Õpetamisest ja õppimisest kirjutades ning räkides väljendame õpikogemusi erinevate keelevahenditega. Nii on eri õpikäsitustes õppimise tähenduse avamisel kasutatud tegevust väljendavaid sõnu, mis eeldatavasti kannavad teksti kirjutajate ja terminite koostajate arusaamu: nt biheivioristlik õpikäsitus on suunatud käitumise muutmisele ning selle kesksed mõisted harjutamine ja jäljendamine toetavad biheivioristlikku õpipoisi mudelit, kus õpetaja on ekspert/meister ja õppija kopeerija/harjutaja. Kognitiivse õpikäsituse puhul pole fookus käitumise muutmisel, vaid tunnetusega seotud protsessidel, selle keskne mõiste omandamine seab õppija vastuvõtja ja õpetaja andja rolli. Lause „Õpetaja õpetab õpilast” loomulikustab ühiskondlikud kokkulepped, mille kohaselt õpetaja on klassiruumis aktiivne tegelane, õpilane aga objekt, kellega midagi tehakse institutsionaalselt ette antud kohas ja ajal ehk formaalõppe tingimustes. Õpetaja- ja ainekeskselt mõeldes nimetatakse õpetajat oma eriala, nt füüsika õpetajaks, lähtudes uskumusest, et õpetaja teadmine tuleb õppijale üle anda ning õppija roll on antud või ette loetud teadmine vastu võtta, omandada, salvestada ja teadmiste kontrolli ajal esitada (Kilp 2017: 20). Siin on viide nii biheivioristlikule õpikäsitusele, kus oodatakse õppija õ i get käitumist, kui ka kognitiivsele õpikäsitusele, mis näeb õppimist teadmiste omandamisena.

Konstruktivistlikus õpikäsituses on keskne tähenduste loomine, mistõttu räägitakse ka õpetajast looja metafoori kaudu: ta on õpikeskkonna tingimuste looja. See rõhutab eelkõige ühe poole aktiivset rolli. Sotsiaalkonstruktivistlikus õpikäsituses on keskne osalemine, koos tegutsemine, ja see toob esile teistsugused inimestevahelised suhted. Larissa Jõgi ja Mari Karm (2013) tõdevad, et kui õppimist kogetakse omandaja rolli ja omandamise protsessi kaudu, räägitakse vähem haridusasutusest, kus õpitakse, uuritakse, luuakse ja avastatakse uut toetavas, eripärases, vaimses ja kriitilist meelt soosivas keskkonnas. Alar Kilp (2017: 20) rõhutab, et kuna õpetamise eesmärk on õppijas toimuv õppimine, peab õpetamise ja õppimise suhe olema korraldatud nii, et see toetaks õppija õppimist: selleks peaks õpetaja õppima õppijalt, õppima koos, õpetama ja looma õppijatega koos ka teadmisi, lähtudes õppijate vajadustest ning õppimise keskkonnast. Seega on sotsiaalkonstruktivistliku käsituse järgi kõik osalejad, k.a õpetaja, õppija rollis. Ka üliõpilaste kogemuste uuring kinnitab, et õppimist ja õpetamist kujutletakse koostoimelise protsessina, kus vahetatakse kogemusi, tehakse koostööd ja luuakse õpitule tähendusi (Karu 2020).

Õpikäsitused on teoreetilistele teadmistele rajatud kirjalike tekstide kogumid, mis mõjutavad teiste tekstide, sh sõnaraamatute sisu, inimeste identiteete ja nende- 
vahelisi suhteid, hoiavad üleval või lõhuvad väljakujunenud hierarhiaid olenevalt sellest, kas keskmes on nt aine, õpetaja, õppija või hoopis kogukonnaliikmete koostöö ja koosloome. Kuid ka neis käsitustes võistlevad üksteisega konfliktis olevad diskursused hegemoonilise positsiooni saavutamise nimel (Fairclough 2005). Eesti haridus- ja teadusstrateegias „Tark ja tegus Eesti 2035” (HTM 2019) käsitletakse õppimist õppijakeskse ja koostöisena, suunatuna iga õppija võimestamisele ja toetamisele, tema eneseteostusele ja toimetulekule. Kui ainekeskses mudelis keskenduti õpetaja teadmiste edastamisele, õppekava täitmisele, testimisele ja eksamitulemustele, siis õppijakeskse lähenemise fookus on õppija motivatsioonil, tema kogemustel; õpetaja roll on luua soodne õpikeskkond (Bachmann 2018). Nüüdisaegses (kasutatakse ka epiteete muиtunud, uиenenud) õpikäsituses rõhutatakse muutusi osalejate rollis ja sotsiaalsetes suhetes koostöisuse suunas ning liikumist konstruktivistliku teadmusloome suunas, õpitava sidumist igapäevaelu teemadega, selmet järgida traditsioonilist teadmiste salvestamise ehk ainekeskset mudelit (Heidmets, Slabina 2017).

„Haridusleksikoni” (Mikser 2013) õppimist avavas peatükis on esindatud sotsiaalkonstruktivistliku õpikäsituse põhimõtted, mille järgi mõistetakse õppimist individuaalses protsessis teadmiste omandamise kõrval sotsiaalse praktikana, kus on oluline õppija kuuluvus ja suhted teistega, mistõttu on tähtis ühises suhtlusruumis koos tegutsemine. Need seisukohad peaksid kajastuma ka eestikeelsete sõnastike õppimise mõistes. Seetõttu on oluline selgitada, kuidas keskseid mõisteid kasutatakse ning kas ja kuidas need kannavad uusi arusaamu õppimisest.

\section{2. Õppimise tähendus sõnastikes}

Õpikäsituste muutunud arusaamad kinnistatakse terminoloogias ja sõnastikes. Üldkeele ja oskuskeele peamine erinevus on täpsusastmes: oskuskeele terminid peavad vastama mõistetele ja nähtustele, mille tähistamiseks neid kasutatakse, vältides polüseemiat ja sünonüümsust (Narits 2002; Kabur 1966). Termin on sõna või sõnaühend, mis kujutab endast märki, millele vastab üks konkreetne mõiste, kusjuures sõnast saab termin alles terminisüsteemis (Erelt 1982: 28). Eesti oskuskeeleõpetuses toonitatakse, et terminilisus on olulisel määral tüve omadus (Saari 1982).

Viiekeelne „Hariduse ja kasvatuse sõnaraamat” (HAR, 2014) ja ka normatiivne „Eesti õigekeelsussõnaraamat ÕS 2018” teevad süstemaatiliselt vahet tüvedel ópe : óppe ja õpp : õpi. Õpe-tüvi on eelkõige kasutusel liitsõnaosana, samuti eristatakse vajaduse korral oskuskeeles õpi- ja óppe-liitsõnu, nt ópimeetod ja õppemeetod (HAR). Nii haridussõnaraamatu kui ka ÕS 2018 kohaselt tähistab sõnatüvi õpe õpetamist, aga ka õppimist ja õpetamist koos, ning sõnatüvi õpp õppimist. Inglise ja saksa keeles tehakse selgemalt vahet õpetamisel ja õppimisel, eesti ja soome keeles see vahe puudub ja vene keeles on sõnaraamatus esitatud ainult üks vaste (HAR): 
õpe $<$ om õppe $>\bullet$ õpetamine; õppimine ja õpetamine koos, õppuri ja õpetaja koostegevus õppeprotsessis

ingl instruction, teaching

sks Unterricht $m$, Lehre $f$

$s m$ opetus, oppiminen, opiskelu

vn обучение

Samal ajal viitab tüvi õpp : õpi võõrkeelsetes terminitõlgetes õppimisele:

õpp $<$ om õpi $>\bullet$ õppimine

ingl learning, study

sks Lernen $n$

sm oppiminen, opiskelu

$v n$ обучение

Haridusleksikoni 30-liikmeline autorkond on õppimise defineerinud individuaalse protsessina, „milles praktilise kogemuse vahendusel kujunevad õpilase tegevusvõimes või käitumises suhteliselt püsivad muutused” (Krull 2013: 270). „Hariduse ja kasvatuse sõnaraamatus" on õppimine defineeritud muutuste ja omandamise mõistete kaudu:

õppimine (1) • protsess, kus kogemuse vahendusel kujunevad (teadvustamata või teadvustatult) suhteliselt püsivad muutused tegevusvõimes või käitumises

õppimine (2) • teadmiste, oskuste, vilumuste, väärtuste, hoiakute jm omandamine

Ka „Eesti keele seletavas sõnaraamatus” (EKSS) on õppimine defineeritud kognitiivse õpikäsituse ja omandamise metafoori kaudu:

\section{õppima «õpin 42>}

1. harjutades ja korrates teadmisi, oskusi, vilumusi omandama (koolis käies, kellegi juhendamisel v. iseseisvalt); harjutades, treenides mingit konkreetset oskust omandama.

2. eeskuju v. kogemuse mõjul mingit kommet, harjumust, hoiakut, käitumisviisi vms. omandama.

Uues üldsõnastike infot koondavas Sõnaveebis (EKI ühendsõnastik 2020) on õppimine samuti defineeritud biheivioristliku ja kognitiivse õpikäsituse järgi, mis näeb seda individuaalse tegevusena:

\section{õppima}

$\mathbf{1}$ harjutades ja korrates teadmisi, oskusi, vilumusi omandama (koolis, kellegi juhendamisel, iseseisvalt)

2 eeskuju, kogemuse mõjul mingit kommet, harjumust, hoiakut, käitumisviisi vms omandama 
Seega sotsiaalkonstruktivistliku õpikäsituse olulised põhimõtted, nagu nt õppija kuuluvus ja suhted teistega, ühises suhtlusruumis koos tegutsemine, ei avaldu hariduse ja kasvatuse sõnastikes ega ka teistes hilisemates sõnaraamatutes. Sarnane olukord on Krista Kerge (2014: 884-885) sõnul hariduse mõistega: haridusleksikonis on hariduse mõiste tõepoolest avatud vastasmõjuna ümbritseva keskkonna ja kultuuriga, ent „Hariduse ja kasvatuse sõnaraamatus” domineerib endistviisi ajastuomane tähenduskonstruktsioon, mis vaatab mööda hariduse subjektist ja tema kultuuriümbrusest.

Kuna sotsiaalkonstruktivistliku käsituse olulised põhimõtted õppimise sõnastikudefinitsioonides ei väljendu, on oluline leida keelevahendid, et lisada õppimise tähendusse koostegutsemise mõõde. Õpi- ja õppe-tüved esinevad sõnastikes liitsõna osadena, milles ruum osutab tegevuskohale, kus sotsiaalkonstruktivistliku õpikäsituse eelduseks olevad suhted ja ühised tegevused saaksid toimuda. Opperuum tähistab Sõnaveebi järgi 'õppetööks, loengupidamiseks ettenähtud ruumi (nt õppeasutuses, koolituskeskuses)', EKSS-i järgi 'õppetööks sisustatud ruumi'. Õpikeskkond on defineeritud kui 'õppimist mõjutavate tegurite kooslus'. „Hariduse ja kasvatuse sõnaraamatus" on õppe- ja õpikeskkonna mõisted samatähenduslikuna avatud kui 'õppimist mõjutavate tegurite (õppemeetodid, õppevahendid, kaasõppurid, õpperuumid, virtuaalne keskkond jm) kooslus', mis tähendab, et mõlema liitsõna puhul on esil õppimise tingimused, mitte protsess. Kuigi õpiruumi mõistet sõnaraamatud ei ava, on sõna kasutusel paralleelselt õpperuumiga. Nimelt on õpiruumi ja õpperuumi mõisted avalikus teabeväljas, meedias leiduvates tarbetekstides (edaspidi: tarbetekstides) paralleelselt kasutusel: päring Station.ee andmebaasist perioodi 2014-2019 kohta näitab, et sõna õpiruum on sisaldanud 87 ja õpperuum 962 artiklit. Nende sõnade kasutuskonteksti ja tähendusvälja tarbetekstides ei ole teadaolevalt veel uuritud.

Praeguste definitsioonide kohaselt tähistab õpperuum niisiis füüsilist ruumi; ópi- ja õppekeskkond õppimist mõjutavate vahendite ja tingimuste kooslust. Aga nagu ka Halliki Põlda ja Gertha Teidla-Kunitsõn (2020) osutavad, pole õpiruumi või õppimise ruumi (ingl learning space) mõiste haridusvaldkonna terminina määratletud, vaid seda kasutatakse tekstides õpikeskkonna (ingl learning environment) sünonüümina, kusjuures viimane tähistab enamasti füüsilist või digitaalset ruumi. Kahe uurimisgrupi sarnane tähelepanek viitab selgelt probleemi olemasolule. Maggi Savin-Badeni (2008: 2017) järgi kajastab õpiruumi mõiste nii füüsilist kui ka psühholoogilist õpikeskkonda, kuhu kuuluvad sotsiaalne õppimine, dialoog ja arutelu, aeg refleksiooniks, vajadusel digitaalse mõttevahetuse võimalus. Mitmed autorid (SavinBaden 2008; Ashwin jt 2015; Karu 2020) rõhutavad, et kui õpiruumi loomisel ja suhtlemisviiside valikul arvestame eri identiteedi, ootuste ja vajadustega õppijatega, siis võimaldame õpiprotsessis aega mõtlemiseks, reflekteerimiseks ja süvaõppimiseks. Sotsiaalkonstruktivistliku õpikäsituse keskmes on kõigi osaliste vastutus, sotsiaalsed suhted, osalemine, koos tegutsemine, ühine pingutus ja panus - väidame, et seda annab edasi just õpiruumi (ja mitte õpikeskkonna) mõiste, millel on potentsiaali rõhutada muutunud arusaamu õppimisest. 


\section{Uuringu ülesehitus}

Meie ettevalmistava uuringu eesmärk oli meedias leiduvate tarbetekstide näitel kirjeldada sõnade õpiruum ja õpperuum kasutuskonteksti ning selgitada, kuidas nendes tekstides väljenduvad hariduses osalejate suhted, mida tähtsustab sotsiaalkonstruktivistlik õpikäsitus. Tarbetekst on mõeldud suurele auditooriumile eesmärgiga informeerida ja edastada „mingi asja sisu”, mistõttu tuleb sellises tekstis kasutada kõigile ühtviisi arusaadavaid, täpse sisuga, neutraalse värvinguga sõnu ja väljendeid (Kasik 2007: 46-47). Arvestades üldlevinud infootsingu praktikat, kitsendasime oma uuringu fookuse Google'i otsingumootoris leitavatele tarbetekstidele. Uurisime nii sõnalist kui ka pildilist materjali, sest piltidel on oluline roll tähenduste edastamisel ja kujundamisel. Erinevalt sõnast edastavad kujutised sõnumit kiiremini ja tervikuna (Dake 2005; Jones 2009) ja avaldavad vastuvõtjale mõju juba enne sõnumi teadvustamist, kujundades eelhäälestust (Barry 2005).

Meie peamine uurimisküsimus oli: millised hariduses osalejate suhted ja õppimise tähendus avalduvad 1) sõnadega õpiruum ja ópperuum tähistatud tarbepiltidel ja 2) neid sisaldavates sõnalistes tarbetekstides?

Analüüsimaterjali leidmiseks tegime kolmekesi paralleelselt sõnadele õpiruum ja ópperuum Google'i pildiotsingu 14. I 2020 ja tekstiotsingu perioodil 20.-31. I 2020. Otsingu loomulikkuse huvides ei puhastanud me varasemat otsinguajalugu ning dokumenteerisime mõlema sõna kohta otsingu 30 esimest teksti- ja 20 pildivastet. Järgmisena võrdlesime üksteise otsitulemusi ja eemaldasime korduvad tekstivasted. Lõppvalimisse jäi ópiruumi kohta 37 teksti ja 22 pilti, ópperuumi kohta 40 teksti ja 21 pilti.

Pildimaterjali võrdlevas sisuanalüüsis kombineerisime kvalitatiivset ja kvantitatiivset analüütilist lähenemist. Esmalt, kvalitatiivse lähenemisena, nimetasime piltide süvavaatluse põhjal esile tulnud tähenduste koodid ehk sisu kirjeldavad märksõnad, sh kirjeldades nii teooria põhjal eelsõnastatud tähendusi (nn suunatud kodeerimine, ingl focused coding) kui ka muid tähendusi (nn avatud kodeerimine, ingl in vivo) (Saldaña 2009; Kuckartz 2014). Seejärel, kvantitatiivse lähenemisena, leidsime koodide esinemissageduse, et võrrelda ópiruumi ja õpperuumi kandvaid tähendusi. Teksti analüüsisime kriitilise diskursuseanalüüsi meetodiga, kuna see võimaldab tekstide keeleliste valikute kaudu esile tuua ühiskondlikud kokkulepped, loomulikustatud tähendused ja inimestevahelised suhted (Gee, Green 1998). Diskursust mõistetakse uuringus kommunikatiivse sündmusena, suhtlusviisina konkreetses sotsiaalses, kultuurilises, ajaloolises ja poliitilises situatsioonis (van Dijk 2005), ruumina, kus luuakse, hoitakse ja muudetakse intersubjektiivseid tähendusi, konstrueerides nii reaalsust (Holzscheiter 2014; vt ka Põlda 2018: 37). Analüüsisime pikemaid lausenäiteid, kus avalduvad diskursuse osaliste ja asjade omavahelised suhted. Nimelt eeldavad tegevused tegijana esile toodud või varjatud inimesi ehk agente (van Leeuwen 1996). Agentiivsus, mis tähendab aktiivse osalise olemasolu suhtlussituatsioonis (EKG II: 24), võimaldab analüüsida tegutsejapositsiooni: isikulise ja umbisikulise tegumoe kasutamise kaudu saab uurida, kes on aktiivne tegutseja, vastutav pool; kes peab etteantud raamistikus tegutsema ja kohanema; kui vorrdsed on hariduses 
osalejate suhted. Tähenduslikuks lugesime ka füüsilise objekti elusana kujutamist. Uurisime, kes tähendusi loovad ehk kes on tekstide autorid. Tekstianalüüsis toetusime ka Norman Fairclough'i (1989, 2005), Katrin Aava, Ülle Salumäe (2013) ja Reet Kasiku (2008) raamistikule, mille kohaselt on analüüsimaterjaliks leksika: väljendid, metafoorid ja epiteedid, millega haridusdiskursustele viidatakse.

\section{Tulemused}

\subsection{Hariduses osalejate suhted ja õppimise tähendus sõnadega õpiruum ja õpperuum tähistatud tarbepiltidel}

Google'i pildiotsingus moodustatud valim koosnes 21 ópperuumi pildist ja 22 õpiruumi pildist. Õpi- ja õpperuumi tähenduse avamiseks sotsiaalkonstruktivistliku õpikäsitluse kontekstis vaatlesime leitud pilte võrdlevalt kolmes analüütilises kategoorias: a) füüsiline ruum (paigutus ja vahendid) ehk millises ruumis ja milliste vahenditega õppimine toimub, b) inimesed ja koostöö ehk kuidas tegutsetakse ja c) õppe sihtgrupp ehk kellele õppimise pilt viitab. Meie leidudest annab ülevaate tabel 1 .

Tabel 1. Sõnadega õpperuum ja õpiruum seotud tarbepiltide sisuanalüüsi tulemused.

\begin{tabular}{|c|c|c|c|c|}
\hline \multirow{2}{*}{$\begin{array}{l}\text { Analüütilised kategooriad ja vaatlustulemus } \\
\text { Pildiotsingu kordustest puhastatud valim }\end{array}$} & \multicolumn{2}{|c|}{ Õpperuumi pildid } & \multicolumn{2}{|c|}{ Opiruumi pildid } \\
\hline & 21 & $100 \%$ & 22 & $100 \%$ \\
\hline \multicolumn{5}{|l|}{ Füüsiline ruum (paigutus ja vahendid) } \\
\hline $\begin{array}{l}\text { Tühjas ruumis sirged pingiread, U-kujuline või } \\
\text { nelinurkne paigutus }\end{array}$ & 8 & $38 \%$ & 0 & $0 \%$ \\
\hline Ruumis projektsioonitahvel ja/või videoprojektor & 8 & $38 \%$ & 0 & $0 \%$ \\
\hline „Õpetaja laud” auditooriumi ees & 7 & $33 \%$ & 0 & $0 \%$ \\
\hline \multicolumn{5}{|l|}{ Inimesed ja koostöö } \\
\hline Inimestega ruumivaated & 7 & $33 \%$ & 13 & $59 \%$ \\
\hline Esitlussituatsioon, inimene seisab auditooriumi ees & 3 & $14 \%$ & 1 & $5 \%$ \\
\hline Õpetaja istub õppijatega ühises ümarlauas & 1 & $5 \%$ & 4 & $18 \%$ \\
\hline Õppijad töötavad ümarlauas iseseisvalt & 2 & $10 \%$ & 6 & $27 \%$ \\
\hline Õppijad ja õpetaja seisavad koostegevuses & 1 & $5 \%$ & 7 & $32 \%$ \\
\hline \multicolumn{5}{|l|}{ Ôppe sihtgrupp } \\
\hline Koolieelikud & 2 & $10 \%$ & 11 & $50 \%$ \\
\hline Kooliealised & 8 & $38 \%$ & 6 & $27 \%$ \\
\hline Täiskasvanud & 9 & $43 \%$ & 1 & $5 \%$ \\
\hline
\end{tabular}

Õpperuumi pildid kujutasid sageli inimesteta ruume, neil esitleti sirgete pingiridade, U-kujulise või nelinurkse paigutusega traditsioonilist klassiruumi (õpiruumi piltidel neid elemente polnud). Ruumis oli sageli esitlustehnika ja/või õpetaja laud pingiridade ees, viidates sellega levinud kooli- või täiskasvanuõppe formaadile (pilt 1). 
Õpiruumi piltidele oli seevastu iseloomulik kergesti liigutatavate mööbliesemetega värvirõõmus ruum, ringis istuvad õppijad tegid omavahel ja õpetajaga koostööd (pilt 2). Märgata ei olnud õpetaja lauda ega videoprojektorit. Pooled meie valimi piltidest olid koolieelsete asutuste (nt lasteaedade) kohta.

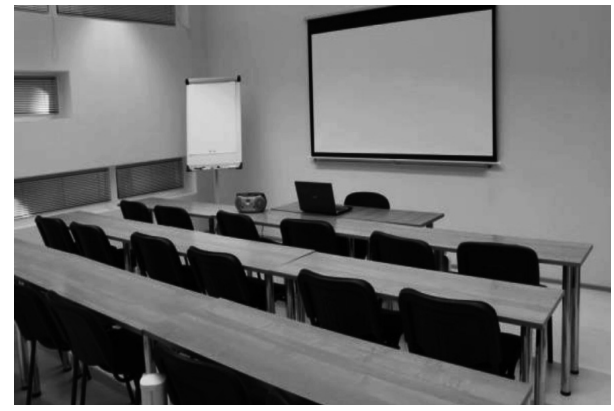

Pilt 1. Õpperuumiga seotud iseloomulik pilt (https://seminariruum.eu/location-room/ kersti-volu-koolituskeskus/opperuum-ii/ (14. I aitab-teisiti-oppida (14. I 2020)). 2020)).

Seega väljendasid meie ettevalmistavas uuringus sõnaotsingutega „õpperuum” ja „õpiruum” leitud tarbepildid sotsiaalkonstruktivistliku õpikäsituse vaatepunktist erinevat ja hariduses osalejate suhete aspektist isegi vastandlikku tähendust. Õpiruumi sõnaga tähistatud piltidel võib suurema tõenäosusega leida dünaamilist, koosloomeliste tegevuste tarbeks paindlikult kujundatavat ruumi, millel on näha nii inimesi kui ka koostegevust. Õpiruumi ülesehitus toetab hariduses osalejate suhtlust ja koostöö tegemist ning seda väljendasid enim koolieelsete asutustega seotud pildid. Õpperuum seevastu märkis sageli ruumi, kus füüsiline/materiaalne keskkond on esiplaanil, viidates, et vahendid on olulisemad kui inimesed ja nendevahelised suhted. Õpperuumi ülesehitus toetab teadmiste edastamist, kuid mitte niivõrd osaliste suhtlust ja koostöö tegemist.

\subsection{Hariduses osalejate suhted ning õppimise tähendus sõnu õpiruum ja õpperuum sisaldavates tarbetekstides}

Google’i otsingus moodustatud tekstiüksuste analüüsi valimisse kaasasime 40 esimest otsisõna õpperuum tulemust ja 37 esimest otsisõna õpiruum tulemust. Päring „õpperuum” näitas esimeses järjekorras teenuste reklaamtekste (nt ruumide rentimiseks), samuti tulid esile tekstid, millega kirjeldati erinevates haridusasutustes, sh autokoolides asuvaid ruume. Mitmed kirjed olid seotud konkursiga „Tuleviku õpperuum 2050”. Üks kirje viis dokumendini „Soovitused töö- ja tehnoloogiaõpetuse õpperuumidele ning keskkonnale" ja ühes anti teada Balti Kaitsekolledži uue õppeklassi avamisest. Asjaolu, et otsisõna õpperuum tõi välja ka käsiraamatu ja artiklikogumiku „Avatud õpiruum”, räägib nende sõnade juhuslikust ja sünonüümsest kasutamisest. 
Õpperuumi kasutatakse koos püsiepiteetidega avatud ja lõimitud eelkõige haridusuuenduse kontekstis (vt tabelit 2). Tekstid on üles ehitatud nii, et isikustatud avatud õpperuum kui aktiivne tegutseja paneb ópetaja kui passiivse tegelase õppija rolli ehk muudab õppes osalejate koostöösuhteid („Avatud õpperuum paneb ka õpetaja õppija rolli”). Sõna õpperuum tähistas ka haridusuuendust digikeskkonnas ning nüüdisaegse õpikäsituse kohast koostöö tegemist, mille agendid on nii õpilased, õpetajad, lapsevanemad kui ka koostööpartnerid.

Tabel 2. Sõnu õpperuum ja õpiruum sisaldanud tarbetekstides esile tulnud peamiste tähenduste ja aladiskursuste võrdlus koos tüüpiliste näidetega.

\begin{tabular}{|c|c|}
\hline Õpperuum & Õpiruum \\
\hline $\begin{array}{l}\text { 1. Ruum üürimiseks, kasutamiseks: } \\
\text { Nutiklassi avar ja hubane õpperuum asub Tartu } \\
\text { vanalinnas. }\end{array}$ & $\begin{array}{l}\text { 1. Nüüdisajastatud ruum üürimiseks, kasuta- } \\
\text { miseks: } \\
\text { Oppiruumi on võimalik pääseda Eesti üliôpilas- } \\
\text { pileti, ISIC-, ITIC-kaardiga. }\end{array}$ \\
\hline $\begin{array}{l}\text { 2. Haridusuuendus: } \\
\text { „Tuleviku ôpperuum 2050!” võitjad. } \\
\text { Epiteetidega avatud, lõimitud on öpperuum } \\
\text { lauses haridusuuenduse agent: } \\
\text { Lõimitud ópperuum ehk kooliruum, mis toetab } \\
\text { muutunud öpikäsitluse ja digipöörde eesmärkide } \\
\text { elluviimist. } \\
\text { Avatud ópperuum paneb ka ôpetaja óppija rolli. }\end{array}$ & 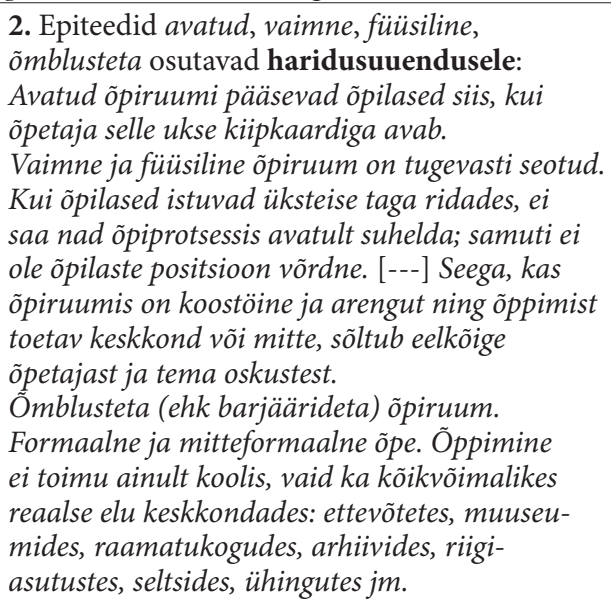 \\
\hline $\begin{array}{l}\text { 3. Koostöö: } \\
\text { Lõimitud ópperuumi projekt on oma olemuselt } \\
\text { kogukonna koostööprojekt, kus kooli ja kodu } \\
\text { kõrval osalevad kohalikud ettevõtjad ja abistajad } \\
\text { kaugemalt. }\end{array}$ & $\begin{array}{l}\text { 3. Koostöö: } \\
\text { Oppiruum on meie koostöö koht. }\end{array}$ \\
\hline
\end{tabular}

37 Google’i sisuotsingu kirjet, mis sisaldavad sõna õpiruum, näitavad sõna esinemist õppematerjalide ja ülikooliruumide tutvustuses. Ülejäänud otsitulemuste hulgas olid õpetajate ja lasteaiaõpetajate blogipostitused, koolitused, linnavalitsuse haridusvaldkonna õppereis, meedialood, kus tutvustati renoveeritud koole, lasteaedade kogumik, „Hea kooli käsiraamat”, kooli kodulehekülg ja arengukava, hariduskonverents, muuseumipedagoogide ajakiri, haridusfoorumi ümarlaud, digitiigri õpilaskonkurss „Tuleviku õpiruum”, rahvusvaheline reaal- ja loodushariduse konverents. Tekstide lähilugemine avas nii ruumi nüüdisajastatud tähendusi kui ka vastandlikke, ärilise eesmärgiga ruumitutvustusi, mis osutasid õpetaja- ja ainekesksele õpikultuurile, olles vastuolus nüüdisaegse ja täiskasvanuõppe põhimõtetega õppimisest. 
Õpiruumi sõna kasutatakse koos haridusuuendusele viitavate epiteetidega uus, uuenenud ning sarnaselt ópperuumiga koos epiteediga avatud. Konstruktsiooni avatud õpiruum kasutatakse sisuliselt vastuolulisena: sellega tähistatakse nüüdisaegset õpikeskkonda, kuhu ligipääs on õpetaja poolt rangelt reglementeeritud („Avatud õpiruumi pääsevad õpilased siis, kui õpetaja selle ukse kiipkaardiga avab"). Avatud ópiruumiga tähistatakse õppimisel koostöö tegemist, mille eest vastutab õpetaja („kas õpiruumis on koostöine ja arengut ning õppimist toetav keskkond või mitte, sõltub eelkõige õpetajast ja tema oskustest"). Seega kerkib esile õpetajakeskne diskursus, kus õpetaja on aktiivses, vastutavas rollis.

Õmblusteta või barjäärideta ópiruumi konstrueeriti individualiseeritud õpiradade ja õppija õppimisvõime parandamise ideede kaudu. Huvi- ja alushariduse kontekstis eristusid tekstid, mis andsid edasi õpiruumi mõistet, lähtudes sotsiaalkonstruktivistlikust õpikäsitusest.

Kokkuvõttes näitavad meie esmase uuringu tulemused, et õpiruumi mõiste toob füüsilise ruumi kõrval selgemalt nähtavale inimesed (õppija ja õpetaja), nendevahelise suhte ja koostöö. See tuli piltidel esile selgemalt kui tarbetekstides. Sellegi poolest oli mõlemat tüüpi tekstides sõnu õpiruum ja õpperuum kasutatud juhuslikult, vastuoluliselt, nii et need kattusid osaliselt või täielikult (sõnu kasutati sünonüümidena).

\section{Arutelu}

Tarbetekste vaatlevas ettevalmistavas uuringus ópiruumi ja ópperuumi kasutuskonteksti ja aladiskursusi avades jõudsime tulemusele, et hetkel pole kummagi liitsõna kasutus selge ja järjekindel: tekstide loojad ei erista ópiruumi ja ópperuumi tähendusi, nt esineb sünonüümset ja seega eksitavat kasutamist. Samuti kasutatakse õpiruumi mõistet kontekstis, millega kinnistatakse seni levinud õpetajakeskse õpikäsituse tähendusi. Õpiruumi mõistet on sageli kasutatud uutest või renoveeritud koolihoonetest rääkivates tekstides. Nendes kirjeldustes on palju ruumi, arhitektuuri ja disainiga seonduvat, mis omakorda hakkab looma mõiste tähendusvälja, keskendudes ruumile, mitte seal toimuvale. Teisalt kasutati õpiruumi sõna ka meediatekstides, mille diskursus loomulikustab haridusteenust, kus õpiruumid on üürimiseks ja kultuur on õpetajakeskne. Õppijat nähakse senises diskursiivses praktikas objektina, mitte autonoomse ja vastutava subjektina, ja see on vastuolus sotsiaalkonstruktivistliku õpikäsitusega (Karu 2020).

Tekstides esitati ruumi kui isikustatud agenti, kes hakkab muutusi ellu kutsuma ja sunnib õpetajat muutuma. Kuigi tekstide loojad lähtuvad justkui eeldusest, et kui ehitatakse valmis uus nüüdisaegne õpikeskkond, hakkab see ise muutust looma, ei pruugi see tegelikult tähendada õpetaja ja õppijate koostööd. See tulemus võib viidata õppijakeskse diskursuse soovimatule mõjule. Gert Biesta (2015) osutab viimastel kümnenditel toimunud uusliberaalsetele muutustele haridusprotsesside ümbermõtestamises, mis lähtuvad majandusloogikast: nii on õppijast saanud potentsiaalne 
tarbija, kellel on kindlad vajadused; õpetaja või haridusasutus on teenuse osutaja ja haridus pakutav kaup.

Naomi Berman (2020) tõstatas küsimuse mitteformaalsete õpiruumide kohta, mida kirjanduses kirjeldatakse vabade, avatud ja kogukondlike koostöökeskkondadena, mis toimivad demokraatlikul viisil ja võimaldavad õppijatel ka tehnoloogilistele võimalustele ligi pääseda. Meie tarbetekstide analüüsi tulemustes see selgelt esile ei tule. Vaadeldud tarbetekstides oli ainult üksikuid näiteid, kus õpiruumi või õpperuumi sõna tähistas teoreetikute sõnastatud (Knowles jt 2005) hariduses osalejate koosloomet (nt „Õpiruum on meie koostöökoht”).

Anname endale aru, et ainult definitsioon ei määra praktikat. Õpiruumi mõistet saab tähenduslikult sisustada alles nüüdisaegse õpikäsituse põhimõtete praktikasse juurutamisel ja siis, kui osalised muutunud haridussuhted heaks kiidavad / vastu võtavad. Uue õpikäsituse kasutusele võtmine ühiskonnas vajab ühiseid jagatud arusaamu, mõtte- ja käitumisviise (Heiskala 2007), uskumuste ning siis praktikate muutust. Õpiruumi sisu avatakse tarbetekstide analüüsi põhjal vanale vastandumise ehk eituse kaudu („Kui õpilased istuvad üksteise taga ridades, ei saa nad õpiprotsessis avatult suhelda"). Seega on oht, et õpiruumi tähendusvälja luuakse vana diskursiivse praktika järgi dotseeriva hinnangulise kõnepruugiga, mis on omane pigem õpetajaja ainekesksele lähenemisele.

Station.ee andmebaasi statistika näitab, et viie aasta jooksul pole õpiruumi sõna kasutus meedias oluliselt kasvanud võrreldes õpperuumi sõnaga. Õpiruum on jätkuvalt vähe kasutatud ja selle sisulist erinevust õpperuumist mõistavad ilmselt ainult spetsialistid, kes teavad õpi- ja õppe- sõnatüve tähendusi. Seni on sõna õpiruum kasutus tarbetekstides isevoolu kujunenud ja sõna ei eristu piisavalt sõna ópperuum tähendusest. Ühtlasi oleks oluline pakkuda ka venekeelsele kogukonnale termin, millega väljendada sotsiaalkonstruktivistliku õpikäsituse põhimõtet. Praegu pakuvad sõnaraamatud nii õpetamise kui õppimise venekeelseks vasteks sõna обучение.

Kuna õppimine toimub mis tahes ajal, paigas ja tehnoloogia abil, kui ressursid on olemas, ning hariduses osalejate rollid ei ole kinnistunud, vaid dünaamilised - õpetaja võtab õppija rolli (Ashwin jt 2015) -, peaks õpiruumi (ingl learning space) definitsioon tähistama aega ja ruumi erinevate sidusgruppide koosloomeks, võimaldades kõigil osapooltel võtta vastutust ning olla võimestatud õppimisprotsessis. Peame vajalikuks, et avalikkus saaks haridusuuenduse olulise võtmesõna eriomasest tähendusest üheselt aru, seda olukorras, kus haridusuuenduse ja uue õpikäsituse kohaselt muutub kogu avalik ruum õpiruumiks ning paljud ühiskonnagrupid saavad potentsiaalseteks koostööpartneriteks hariduses osalejad. Põlda ja Teidla-Kunitsõn (2020) näitavad sotsiaalse õpiruumi mõiste kasutuselevõtu vajadust, et rõhutada õpperuumi osana uute tehnoloogiate kasutuselevõtuga tekkinud võimalusi ning arvestada õpikogukondadega. Samal ajal rõhutab õpiruumi termin sotsiaalseid suhteid niikuinii, sest sõnatüvi õpi- viitab hariduses osalejate võrdsetele rollidele ja vastutusele õppijatena. Seda on oluline mõista ja see tähendus võiks ühiskonnas laiemalt õppimise mõistele lisanduda. 
Õpiruumi termini sõnastamise (tulevikuarutelu) lähtepunktiks pakume sõnaraamatute ja leksikonide koostajatele järgmise definitsiooni:

\section{õpiruum}

osaliste koostöös õpitule tähenduse loomise ruum. Kogukondlik, virtuaalne ópiruum. Linnaruum, lennujaam, haridusfoorum, ülikool kui öpiruum.

\section{VEEBIVARAD}

EKI ühendsõnastik 2020. Eesti Keele Instituut, Sõnaveeb 2020. https://sonaveeb.ee EKSS = Eesti keele seletav sõnaraamat 2009. https://www.eki.ee/dict/ekss HAR = Haridussõnastik 2014. https://www.eki.ee/dict/haridus Station.ee. [Meediamonitooringu ja -analüüsi teenus.] https://station.ee ÕS 2018 = Eesti õigekeelsussõnaraamat ÕS 2018. https://www.eki.ee/dict/qs

\section{KIRJANDUS}

Aava, Katrin; Salumäe, Ülle 2013. Meedia ja mõjutamine. Tallinn: Künnimees.

Ashwin, Paul; Boud, David; Coate, Kelly; Hallett, Fiona; Keane, Elaine; Krause, Kerri-Lee; Leibowitz, Brenda; MacLaren, lain; McArthur, Jan; McCune, Velda; Tooher, Michelle 2015. Reflective Teaching in Higher Education. London-New Delhi-New York-Sydney: Bloomsbury.

Bachmann, Heinz 2018. A focus on student learning. - Competence-Oriented Teaching and Learning in Higher Education - Essentials. Toim H. Bachmann. Bern: hep der Bildungsverlag, lk 12-14.

Barry, Ann Marie 2005. Perception theory. - Handbook of Visual Communication: Theory, Methods, and Media. Toim Ken Smith, Sandra Moriarty, Gretchen Barbatsis, Keith Kenney. Routledge, lk 45-62.

Berman, Naomi 2020. A critical examination of informal learning spaces. - Higher Education Research \& Development, kd 39, nr 1, lk 127-140.

Biesta, Gert 2015. What is education for? On good education, teacher judgement, and educational professionalism. - European Journal of Education, kd 50, nr 1, lk 75-87.

Dake, Dennis 2005. Creative visualization. - Handbook of Visual Communication: Theory, Methods, and Media. Toim Ken Smith, Sandra Moriarty, Gretchen Barbatsis, Keith Kenney. Routledge, lk 23-43.

EKG II = Tiiu Erelt, Reet Kasik, Helle Metslang, Henno Rajandi, Kristiina Ross, Henn Saari, Kaja Tael, Silvi Vare 1993. Eesti keele grammatika II. Süntaks. Tallinn: Eesti Teaduste Akadeemia Keele ja Kirjanduse Instituut.

Erelt, Tiiu 1982. Eesti oskuskeel. Tallinn: Valgus.

Fairclough, Norman 1989. Language and Power. Edinburgh: Pearson Education.

Fairclough, Norman 2005. Critical discourse analysis in trans-disciplinary research on social change: Transition, re-scaling, poverty and social inclusion. - Lodz Paper in Pragmatics, kd 1, lk 37-58. 
Gee, James Paul; Green, Judith, L. 1998. Discourse analysis, learning, and social practice: A methodological study. - Review of Research in Education, kd 23, nr 1, lk 119-169.

Granito, Vincent J.; Santana, Mary E. 2016. Psychology of learning spaces: Impact on teaching and learning. - Journal of Learning Spaces, kd 5, nr 1, lk 1-8.

Heidmets, Mati; Slabina, Pille 2017. Õpikäsitus kooliuuenduse kontekstis. - Õpikäsitus: teooriad, uurimused, mõõtmine. Analüütiline ülevaade. Toim M. Heidmets. Tallinna Ülikool: Haridusteaduste Instituut, lk 4-8.

Heiskala, Risto 2007. Social innovations: Structural and power perspectives. - Social Innovations, Institutional Change and Economic Performance. Toim Timo J. Hämäläinen, R. Heiskala. Cheltenham: Edward Elgar, lk 52-79.

Holzscheiter, Anna 2014. Between communicative interaction and structures of signification: Discourse theory and international relations. - International Studies Perspectives, $\mathrm{kd} \mathrm{15,} \mathrm{nr} \mathrm{2,} \mathrm{lk} \mathrm{142-162.}$

HTM 2017 = Haridus- ja Teadusministeerium. Õpikäsitusest ja selle muutumisest. Elukestva õppe strateegia 2020 1. eesmärgi selgituseks. https://www.hm.ee/sites/default/files/har_ min_broshyyr_12lk_est_veebi.pdf (16. II 2020).

HTM 2019 = Haridus- ja Teaduministeerium. Tark ja tegus Eesti 2035. Eesti haridus- ja teadusstrateegia 2021-2035. Kolme ekspertrühma visioonidokumentide kokkuvõte. https:// www.hm.ee/sites/default/files/tark_ja_tegus_eesti2035_kokkuvottev_visioonidokument.pdf (18. VIII 2020).

Jones, Kevin 2009. The persuasive function of the visual ideograph: The case of baby Samuel. - Visual Impact: The Power of Visual Persuasion. Toim Susan B. Barnes. Cresskill, New Jersey: Hampton Press, lk 173-184.

Jõgi, Larissa; Karm, Mari 2013. Õppejõudude õpetamisoskusest. - Sirp 7. II.

Kabur, Helve 1966. Teoreetilist termini ja üldsõna vahekorra kohta. - Keel ja Kirjandus, nr 7, lk 426-431.

Karu, Katrin 2020. Üliõpilaste arusaamad õppimisest ülikoolis: andragoogiline vaade. (Tallinna Ülikooli sotsiaalteaduste dissertatsioonid 134.) Tallinn: Tallinna Ülikooli Kirjastus.

Kasik, Reet 2007. Kuidas kirjutada selget tarbeteksti. - Oma Keel, nr 1, lk 46-51.

Kasik, Reet 2008. Meediatekstide analüüs: eesmärgid ja metoodika. - Tekstid ja taustad V. Toim R. Kasik. Tartu: Tartu Ülikooli Kirjastus, lk 10-43.

Kerge, Krista 2014. Haridusmõisteid kuues kuues. - Keel ja Kirjandus, nr 11, lk 877-887.

Kilp, Alar 2017. Akadeemiline õpetamine. - Sõjateadlane, nr 4, lk 9-34.

Knowles, Malcolm S.; Holton, Elwood F.; Swanson, Richard 2005. The Adult Learner: The Definitive Classic in Adult Education and Human Resource Development. Amsterdam: Elsevier.

Krull, Edgar 2013. Õppimine. - Haridusleksikon. Toim Rain Mikser. Tallinn: Eesti Keele Sihtasutus, lk 270-275.

Kuckartz, Udo 2014. Basic concepts and the process of qualitative text analysis. - Qualitative Text Analysis: A Guide to Methods, Practice \& Using Software. Toim U. Kuckartz. London: SAGE Publications Ltd., lk 37-64.

Kuurme, Tiiu 2015. Õppimise mõistmisest (2. osa). - Huvitav kool 16. I. https://www.huvitavkool.ee/2015/01/tiiu-kuurme-oppimise-moistmisest-2osa.html (13. VIII 2020). 
Merriam, Sharan B.; Caffarella, Rosemary S.; Baumgartner, Lisa M. 2007. Learning in Adulthood. 3rd ed. San Francisco: Jossey-Bass.

Mikser, Rain (toim) 2013. Haridusleksikon. Tallinn: Eesti Keele Sihtasutus.

Mikser, Rain 2014. „Haridusleksikon”. - Eesti Haridusteaduste Ajakiri, kd 2, nr 2, lk 242-244.

Narits, Paul 2002. Juriidiline semantika ehk õiguskeel Eesti õiguskorra kontekstis. - Riigikogu Toimetised, nr 5, lk 112-116.

Põlda, Halliki 2018. Andekusefenomeni konstrueerimine avalikus kommunikatsioonis. (Tallinna Ülikooli sotsiaalteaduste dissertatsioonid 48.) Tallinn: Tallinna Ülikooli Kirjastus.

Põlda, Halliki; Teidla-Kunitsõn, Gertha 2020. Õpiruumi keeleline konstrueerimine üliõpilaste arusaamades. - Keel ja Kirjandus, nr 8-9, lk 719-736.

Saari, Henn 1982. Eesti terminoloogiatöö põhimõtete analüüs. Kandidaaditöö. Tartu: Tartu Riiklik Ülikool.

Saldaña, Johnny 2009. The Coding Manual for Qualitative Researchers. London: Sage Publications Ltd.

Savin-Baden, Maggi 2008. Learning Spaces: Creating Opportunities for Knowledge Creation in Academic Life. Maidenhead: University Press.

Säljö, Roger 2003. Õppimine tegelikkuses. Tlk Erle Nõmm. Eesti Vabaharidusliidu Kirjastus. Tynjälä, Päivi; Heikkinen, Hannu L. T.; Huttunen, Rauno 2005. Konstruktivistinen oppimiskäsitys oppimisen ohjaamisen perustana. - Konstruktivismi ja realismi. Toim Pekka Kalli, Anita Malinen. Helsinki: Kansanvalistusseura ja Aikuiskasvatuksen tutkimusseura, lk 20-48.

van Dijk, Teun A. 2005. Ideoloogia. Multidistsiplinaarne käsitlus. Tlk Merit Karise. Tartu: Tartu Ülikooli Kirjastus.

van Leeuwen, Theo 1996. The representation of social actors. - Texts and Practices: Readings in Critical Discourse Analysis. Toim Carmen Rosa Caldas Coulthard, Malcolm Coulthard. London: Routledge, lk 32-70.

Katrin Aava (snd 1963), PhD, Tallinna Ülikooli Balti filmi, meedia, kunstide ja kommunikatsiooni instituudi (BFM) dotsent (Narva maantee 25, 10120 Tallinn), aava@tlu.ee

Katrin Karu (snd 1969), PhD, Tallinna Ülikooli haridusteaduste instituudi andragoogika lektor (Narva mnt 25, 10120 Tallinn), katrin.karu@tlu.ee

Esta Kaal (snd 1962), MA, Tallinna Ülikooli Balti filmi, meedia, kunstide ja kommunikatsiooni instituudi (BFM) lektor (Narva mnt 25, 10120 Tallinn), esta.kaal@tlu.ee

Mari Uusküla (snd 1980), PhD, Tallinna Ülikooli humanitaarteaduste instituudi lingvistika ja tõlketeaduse dotsent (Narva mnt 29, 10120 Tallinn), mari.uuskula@tlu.ee 


\section{Õpiruum 'learning space' or õpperuum 'study space'? The use of the right term conveys the meaning of the learning process}

Keywords: concept of learning, educational terminology, dictionary, field of meaning, discourse analysis

In our article we conceptualise the meaning of the Estonian words oppiruum 'learning space' and oppperuum 'study space' by analysing media texts retrieved from the Internet. A media text, as we understand it, is any constructed media product or piece of communication, whether printed or audiovisual, which can be analysed and deconstructed. Until recently, the two terms õpiruum and opperuum have been used inconsistently and all too often as synonyms in Estonian. By presenting several examples and pictures from media texts we argue that these two terms should rather be used in different contexts and definitely not used as synonyms. A closer look at the uses of these two terms in dictionaries enables us to construct the meaning of the word stems ofpi- and oppe-. The textual and visual material retrieved from the Internet gives multiple, vague and contradictory responses. In texts, ópiruum and opperuum are almost invariably used as synonyms. Visual examples, however, allow to conclude that ofpiruum is usually an open space where students have active roles, the room itself allows certain mobility and flexibility, and the process taking place in this room could be characterised as co-creation between students and teacher. On the contrary, ofpperuum is a room which does not allow any flexibility or mobility, the role of the students is rather passive as only the teacher has an active role and the process taking place in this kind of room could be characterised as a one-way-path from a teacher who teaches and the students who are there to study. We suggest that the two terms ofpiruum and opperuum should be used in different ways and we propose to define ópiruum as follows: ópiruum 'learning space' is a space where parties in the learning process establish the meaning of what is being learnt together.

Katrin Aava (b. 1963), PhD, Tallinn University, Baltic Film, Media, Arts and Communication School (BFM), Associate Professor (Narva mnt 25, 10120 Tallinn), aava@tlu.ee

Katrin Karu (b. 1969), PhD, Tallinn University, Institute of Educational Sciences, Lecturer in Andragogy (Narva mnt 25, 10120 Tallinn), katrin.karu@tlu.ee

Esta Kaal (b. 1962), MA, Tallinn University, Baltic Film, Media, Arts and Communication School (BFM), Lecturer (Narva mnt 25, 10120 Tallinn), esta.kaal@tlu.ee

Mari Uusküla (b. 1980), PhD, Tallinn University, School of Humanities, Associate Professor of Linguistics and Translation Theory (Narva mnt 29, 10120 Tallinn),

mari.uuskula@tlu.ee 